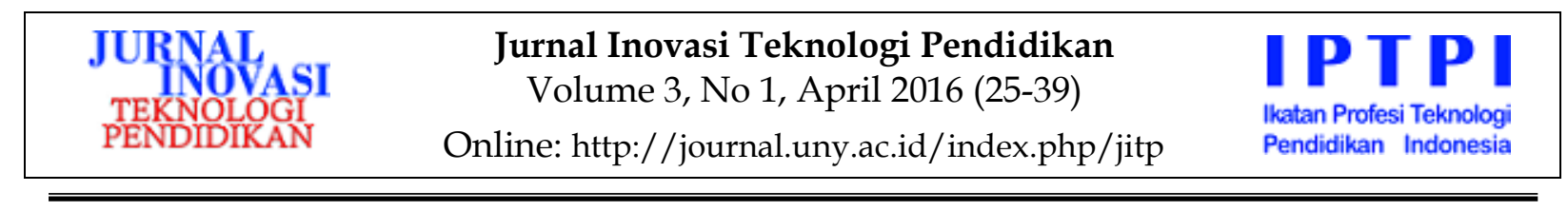

\title{
PENGEMBANGAN MULTIMEDIA PEMBELAJARAN BAHASA INGGRIS UNTUK PEMBELAJARAN TEKS RECOUNT DI MTsN II YOGYAKARTA
}

\author{
Muhammad Ahmad Jumasa1, Herman Dwi Surjono² \\ Teknologi Pembelajaran Universitas Negeri Yogyakarta1, FT Universitas Negeri Yogyakarta² \\ muhammad.ahmad.jumasa@gmail.com, hermansurjono@uny.ac.id
}

\section{Abstrak}

Penelitian ini bertujuan untuk: (1) menghasilkan produk multimedia pembelajaran bahasa Inggris untuk pembelajaran teks recount, (2) mengetahui kelayakan produk multimedia pembelajaran bahasa Inggris untuk pembelajaran teks recount, dan (3) mengetahui keefektifan produk multimedia pembelajaran bahasa Inggris untuk pembelajaran teks recount untuk siswa kelas VIII MTsN II Yogyakarta. Penelitian ini merupakan penelitian dan pengembangan $(R \& D)$ yang diadaptasi dari model Alessi and Trollip yang terdiri dari tiga tahapan yaitu: (1) perencanaan, (2) desain, dan (3) pengembangan. Pengumpulan data melalui observasi, wawancara, lembar angket, dan tes. Data yang diperoleh dianalisis secara deskriptif kuantitatif. Keefektifan produk dianalisis menggunakan rumus $N$-gain (hasil belajar yang dinormalisasi). Hasil penelitian adalah sebagai berikut. (1) produk yang dihasilkan adalah multimedia berbentuk CD pembelajaran bahasa Inggris untuk pembelajaran teks recount yang terdiri dari petunjuk, Standar Kompetensi dan Kompetensi Dasar (SK dan KD), uraian materi, rangkuman, kuis, dan evaluasi; (2) produk yang dikembangkan layak digunakan sebagai media pelengkap pembelajaran bahasa Inggris untuk pembelajaran teks recount; (3) peningkatan skor rata-rata seluruh siswa dari hasil pretest dan posttest sebesar 0,90 ( $N$-gain $\geq 0.7)$. Hal ini berarti keefektifan produk yang dikembangkan termasuk kategori tinggi.

Kata kunci: pengembangan multimedia, pembelajaran bahasa inggris, teks recount, madrasah tsanawiyah, MTsN II Yogyakarta.

\section{DEVELOPING ENGLISH TEACHING MULTIMEDIA FOR TEACHING RECOUNT TEXTS IN MTSN II YOGYAKARTA}

Muhammad Ahmad Jumasa ${ }^{1}$, Herman Dwi Surjono ${ }^{2}$

Teknologi Pembelajaran Universitas Negeri Yogyakarta' ${ }^{1}$, FT Universitas Negeri Yogyakarta ${ }^{2}$ muhammad.ahmad.jumasa@gmail.com, hermansurjono@uny.ac.id

\section{Abstract}

This research aims to: (1) produce English teaching multimedia product for teaching recount texts, (2) find out the appropriateness of English teaching multimedia product for teaching recount texts, and (3) discover the effectiveness of English teaching multimedia product for teaching recount texts for class VIII students of MTsN II Yogyakarta. This research is a research and development adapted from Alessi and Trollip model. The model comprised three steps: (1) planning, (2) design, and (3) development. The data were collected through observation, interview, questionnaire, and test. The obtained data were analyzed quantitative descriptively. The product effectiveness was analyzed using the $N$-gain formula (normalized learning outcomes). The research results are as follows. (1) The developed product is English teaching multimedia in $C D$ for teaching recount texts consisting of guidance, competency standards and basic competencies, material description, summary, quiz, and evaluation. (2) The developed product is appropriate to use as a complementary English teaching media for teaching recount texts; (3) The gaining of the mean score of all students from the result of the pretest and posttest is 0.90 ( $N$-gain $\geq 0.7)$. This means that the effectiveness of the developed product is in a high category.

Keywords: multimedia development, English teaching, recount texts, madrasah tsanawiyah, MTsN II Yogyakarta. 


\section{Pendahuluan}

Mempelajari bahasa Inggris sangatlah penting karena bahasa Inggris merupakan bahasa global yang digunakan secara internasional. Peraturan Pemerintah No 32 Tahun 2013 Pasal 77J Ayat (1) Huruf C tentang Standar Nasional Pendidikan disebutkan bahwa bahasa asing terutama bahasa Inggris merupakan bahasa Internasional yang sangat penting kegunaannya dalam pergaulan global. Oleh karena itu dalam mempelajari bahasa Inggris, pembelajaran harus secara efektif dilakukan. Guru dapat menggunakan alat bantu mengajar agar menarik perhatian siswa. Parel dan Jain (2008, pp. 57-58) menyebutkan ada tiga macam alat bantu mengajar, yaitu alat bantu visual, audio dan audio visual. Alat-alat bantu mengajar tersebut dapat dipilih oleh guru agar sesuai dengan kemampuan berbahasa (membaca, mendengar, berbicara, menulis) yang akan diajarkan. Alat bantu visual seperti gambar memiliki manfaat yaitu mampu menyampaikan makna dan mampu menarik perhatian siswa (Harmer, 2007, pp. 178-179). Alat bantu audio mampu meningkatkan kemampuan mendengar (Heinick, et.al, 1996, p. 178). Alat bantu audio visual dapat meningkatkan perhatian dan motivasi siswa karena melalui alat bantu ini kedua mata dan telinga siswa menjadi aktif (Parel dan Jain, 2008, p. 64).

Multimedia diharapkan menjadi alat bantu mengajar yang akan membuat pembelajaran efektif karena multimedia merupakan gabungan elemen-elemen visual, audio, dan audio visual; seperti gambar, teks, suara, animasi, dan video. Vaughan (2011, p 1) mengemukakan bahwa multimedia merupakan kombinasi dari teks, gambar, suara, animasi, dan video yang disampaikan melalui peranti komputer, elektronik, atau alat hasil rekayasa digital lainnya. Oleh sebab itu, multimedia pembelajaran sangat penting untuk dikembangkan agar pembelajaran bahasa Inggris menjadi efektif.
MTsN II Yogyakarta merupakan sekolah islami dengan fasilitas yang sangat baik dan lengkap namun belum dimanfaatkan secara optimal. Berdasarkan observasi pada tanggal 9 November 2013, fasilitas yang dimiliki yaitu laboratorium komputer dengan 36 unit komputer dan monitor layar datar. Komputer pada laboratorium memiliki spesifikasi prosesor Pentium Dual Core, RAM DDR II 1 GB, dan Sistem Operasi Windows 7. Selain itu, disetiap kelas telah memiliki LCD proyektor yang dapat dimanfaatkan oleh guru untuk mengajar. Kekurangan yang terdapat pada sekolah tersebut adalah pembelajaran bahasa Inggris kelas VIII dengan menggunakan program multimedia pembelajaran belum pernah ada. Dengan demikian, sekolah ini memiliki potensi yang dapat dikembangkan khususnya penggunaan program multimedia pembelajaran untuk pembelajaran bahasa Inggris.

Adapun materi bahasa Inggris yang sangat sulit untuk dipelajari oleh siswa di MTsN II Yogyakarta adalah materi teks recount. Hal tersebut dibuktikan dari nilai ulangan harian siswa pada materi teks recount yang masih berada dibawah nilai Kriteria Ketuntasan Minimal (KKM) jika dibandingkan dengan nilai ulangan harian siswa pada materi teks-teks yang lain seperti teks fungsional, dan teks dektriptif. Nilai kriteria ketuntasan minimal yang telah ditentukan yaitu 75. Pada ulangan harian materi teks recount di kelas VIII G, siswa yang mendapatkan nilai dibawah nilai KKM berjumlah delapan orang siswa, siswa yang mendapatkan nilai sama dengan nilai KKM berjumlah tujuh orang siswa, sedangkan siswa yang mendapatkan nilai diatas nilai KKM berjumlah delapan orang siswa. Pada ulangan harian materi teks fungsional di kelas VIII G, tidak ada siswa yang mendapatkan nilai dibawah nilai KKM. Siswa yang mendapatkan nilai sama dengan nilai KKM berjumlah tujuh orang. Siswa yang mendapatkan nilai di atas nilai KKM berjumlah 16 orang siswa. Pada ulangan harian materi teks deskriptif di kelas VIII G, siswa yang mendapatkan 
nilai dibawah nilai KKM berjumlah tiga orang siswa, siswa yang mendapatkan nilai sama dengan nilai KKM berjumlah dua orang siswa, dan siswa yang mendapatkan nilai diatas nilai KKM berjumlah 18 orang siswa. Teks recount adalah jenis teks tentang cerita, tindakan, atau aktivitas.yang bertujuan untuk menghibur atau memberi informasi kepada pembacanya. Jenis teks ini menggunakan bentuk past tense dengan kata kerja masa lampau untuk menceritakan pengalaman seseorang di masa lalu. Materi teks ini diajarkan untuk siswa kelas VIII pada semester 1. Berdasarkan hasil wawancara yang dilaksanakan pada tanggal 9 November 2013 dengan guru bahasa Inggris kelas VIII G, materi teks recount merupakan materi yang sulit bagi siswa. Kesulitan-kesulitan yang dihadapi oleh siswa menurut guru adalah siswa mengalami kesulitan dalam menyusun rangkaian peristiwa atau cerita berbentuk paragraf acak dari teks recount. Selanjutnya siswa masih belum memahami perubahan bentuk kata kerja masa lampau dalam teks recount dan juga kosakata yang dimiliki siswa sedikit. Setelah mendapatkan keterangan dari guru maka prasurvei dilakukan pada tanggal 29 Maret 2014 dengan 23 siswa kelas VIII G MTsN II Yogyakarta untuk melengkapi keterangan tersebut. Berdasarkan prasurvei terlihat bahwa 23 siswa mengalami kesulitan untuk merangkai paragraf teks recount acak, 20 siswa dari 23 siswa mengalami kesulitan untuk merubah kata kerja masa sekarang menjadi kata kerja masa lampau, dan 23 siswa mengalami kesulitan untuk merangkai kata-kata acak menjadi 1 kalimat utuh. Hasil prasurvei juga menunjukkan bahwa penguasaan kosakata siswa kurang yang terlihat ketika 23 siswa merasa kesulitan merangkai paragraf teks recount acak, 20 siswa dari 23 siswa merasa kesulitan merubah kata kerja masa sekarang menjadi kata kerja masa lampau seperti sell (menjual) menjadi buy dan selled, am menjadi amed, buy (membeli) menjadi buyed dan buying, are menjadi was, where, when dan ared, dan 23 siswa masih kesulitan merang- kai kata-kata acak menjadi 1 kalimat utuh yang dibuktikan pada saat siswa hanya mampu merangkai kalimat I was.

Kebanyakan siswa menyukai belajar diiringi dengan musik. Hasil prasurvei memperlihatkan bahwa 17 siswa menyukai belajar diiringi dengan musik, lima siswa menyukai belajar tidak diiringi dengan musik, dan satu siswa tidak menjawab pertanyaan tentang kesukaan belajar diiringi dengan musik pada angket prasurvei. Oleh sebab itu, multimedia pembelajaran dengan iringan musik diharapkan dapat membantu siswa yang memiliki kegemaran belajar dengan diiringi musik untuk belajar bahasa Inggris materi teks recount. Menurut Harmer (2007, p. 319), musik bermanfaat untuk menghibur dan dapat menghubungkan dengan sangat baik lingkungan yang santai dan lingkungan pembelajaran di dalam kelas.

Hasil prasurvei juga menunjukkan bahwa pembelajaran bahasa Inggris materi teks recount di dalam kelas telah menggunakan media video dan gambar tetapi penggunaan media-media tersebut belum terpadu. Oleh karena itu, pembelajaran bahasa Inggris dengan menggunakan multimedia pembelajaran diharapkan menjadi solusi dengan menggabungkan media berupa gambar dan video menjadi satu kesatuan media agar dapat memudahkan siswa dalam belajar. Berdasarkan latar belakang masalah yang telah diuraikan di atas, pengembangan multimedia pembelajaran untuk mempelajari teks recount di MTsN II Yogyakarta sangat perlu dilakukan.

Penelitian ini bertujuan untuk menghasilkan produk multimedia pembelajaran bahasa Inggris untuk pembelajaran teks recount, mengetahui kelayakan produk multimedia pembelajaran bahasa Inggris untuk pembelajaran teks recount, dan mengetahui keefektifan produk multimedia pembelajaran bahasa Inggris untuk pembelajaran teks recount untuk siswa kelas VIII MTsN II Yogyakarta. 


\section{Metode Penelitian}

Penelitian yang dilakukan termasuk dalam penelitian pengembangan (Research and Development). Hasil dari penelitian ini berupa produk multimedia pembelajaran bahasa Inggris untuk pembelajaran teks recount untuk siswa kelas VIII di MTsN II Yogyakarta yang dibuat dengan menggunakan program Adobe Flash CS5 dan program pendukung lain.

Model pengembangan multimedia pembelajaran dalam penelitian ini mengacu pada Alessi dan Trollip (2001, p. 410). Model pengembangan dari Allessi dan Trollip mencakup tiga langkah yang terdiri dari perencanaan, desain, dan pengembangan. Evaluasi pada model pengembangan multimedia pembelajaran ini berlangsung dalam tiga tahap, yaitu uji Alpha (Alpha Testing), uji Beta (Beta Testing), dan validasi program.

Tempat penelitian adalah di MTsN II Yogyakarta. Penelitian dimulai pada tanggal 24 November 2014 hingga 20 Januari 2015. Subjek uji coba penelitian adalah siswa MTsN II Yogyakarta kelas VIII C dan G. Jumlah subjek uji coba yaitu masing-masing siswa dalam 1 kelas. Rinciannya adalah kelas VIII C berjumlah 33 siswa untuk kegiatan uji beta (beta testing) dan kelas VIII G berjumlah 34 siswa untuk kegiatan validasi program (pretest, uji coba produk, dan posttest).

Langkah-langkah pada penelitian ini meliputi: tahap perencanaan, desain, dan pengembangan. Tahap perencanaan yaitu: mengidentifikasi bidang/ruang lingkup materi teks recount, mengidentifikasi karakteristik siswa, mengidentifikasi kebutuhan teknis, mengumpulkan dan menentukan sumber-sumber, dan melakukan diskusi ide awal. Tahap desain yaitu: membuat flowchart, membuat storyboard, dan menyiapkan skrip. Tahap pengembangan meliputi: menyiapkan teks, warna, gambar, audio dan video, menggabungkan bagianbagian dalam program Adobe Flash CS 5, melakukan evaluasi dengan uji Alpha (Alpha Testing), melakukan evaluasi de- ngan uji Beta (Beta Testing), menghasilkan produk akhir, dan validasi program.

Jenis data dalam penelitian ini adalah jenis data kuantitatif yang diperoleh dari angket yang telah diberikan kepada ahli media, ahli materi, dan siswa kelas VIII MTsN. Data kuantitatif tersebut dikonversikan menjadi data kualitatif. Data yang digali dalam penelitian ini adalah sebagai berikut. Pertama adalah ketepatan materi untuk ketercapaian kompetensi pembelajaran di MTsN II Yogyakarta. Aspek yang dikaji adalah aspek pembelajaran dan aspek isi. Data diperoleh dengan kuisoner dari ahli materi.

Kedua adalah ketepatan rancangan software multimedia pembelajaran. Aspek yang dikaji adalah aspek tampilan dan aspek pemrograman. Data diperoleh dengan kuisoner dari ahli media. Ketiga adalah aspek layak dari multimedia pembelajaran. Data diperoleh dengan kuisoner dari siswa.

Pengumpulan data selama proses pengembangan multimedia pembelajaran bahasa Inggris untuk pembelajaran teks recount menggunakan teknik observasi, wawancara, angket dan tes. Instrumen yang digunakan dalam mengumpulkan data berupa instrumen penilaian untuk menilai produk yang telah dikembangkan dari aspek instruksional, aspek isi, aspek tampilan, aspek pemrograman. Untuk mengetahui penilaian dari siswa secara mendalam terhadap produk multimedia pembelajaran yang dikembangkan, maka peneliti menggunakan instrumen penilaian dari aspek pembelajaran, aspek materi, dan aspek tampilan. Sebelum instrumen penilaian diberikan, instrumen tersebut divalidasi terlebih dahulu oleh validator ahli.

Data hasil penelitian ini berupa tanggapan ahli materi, ahli media, dan siswa tentang kualitas produk yang telah dikembangkan yang ditinjau dari aspek pembelajaran, aspek materi, dan aspek media. Data berupa komentar, saran revisi, dan hasil pengamatan peneliti selama proses ujicoba dianalisis secara deskriptif kua- 
litatif, dan disimpulkan sebagai masukan untuk memperbaiki atau merevisi produk yang telah dikembangkan. Sedangkan data berupa skor tanggapan ahli materi, ahli media, dan siswa yang diperoleh dari kuesioner, dianalisis secara deskriptif kuantitatif dengan menggunakan teknik kategorisasi yang mengacu pada acuan rumus dari Sukardjo dan Sari (2008, pp. 82-86).

Data yang diperoleh dari kuesioner tentang tanggapan siswa diubah menjadi data interval dengan kriteria sebagai berikut: 1 = sangat kurang; 2 = kurang; $3=$ cukup; 4 = baik; dan 5 = sangat baik. Dalam kuisioner diberi lima pilihan untuk memberikan tanggapan terhadap produk multimedia yang dihasilkan. Apabila siswa, ahli materi, dan ahli media memberi tanggapan "sangat baik" pada butir pernyataan yang diberikan, maka skor butir pernyataan tersebut sebesar " 5 ". Skor yang didapat kemudian dikonversikan menjadi data kualitatif skala lima, dengan acuan rumus yang dikutip dari Sukardjo dan Sari (2008, pp. 82-86) pada Tabel 1.

Tabel 1. Kriteria Penilaian

\begin{tabular}{cccc}
\hline Nilai & Rumus & Pkor & Kriteria \\
\hline 5 & $\mathrm{X}>\overline{\mathrm{X}} \mathrm{i}+1,8 \mathrm{SBi}$ & $\mathrm{X}>4,08$ & $\begin{array}{c}\text { Sangat } \\
\text { baik }\end{array}$ \\
4 & $\overline{\mathrm{X}} \mathrm{i}+0,6 \mathrm{SBi}<\mathrm{X} \leq \overline{\mathrm{X}} \mathrm{i}+1,8 \mathrm{SBi}$ & $3,36<\mathrm{X} \leq 4,08$ & Baik \\
3 & $\overline{\mathrm{X}} \mathrm{i}+0,6 \mathrm{SBi}<\mathrm{X} \leq \overline{\mathrm{X}} \mathrm{i}+0,6 \mathrm{SBi}$ & $2,64<\mathrm{X} \leq 3,36$ & Cukup \\
2 & $\overline{\mathrm{X}} \mathrm{i}-1,8 \mathrm{SBi}<\mathrm{X} \leq \overline{\mathrm{X}} \mathrm{i}-0,6 \mathrm{SBi}$ & $1,92<\mathrm{X} \leq 2,64$ & Kurang \\
1 & $\mathrm{X} \leq \overline{\mathrm{X}} \mathrm{i}-1,8 \mathrm{SBi}$ & $\mathrm{X} \leq 1,92$ & $\begin{array}{c}\text { Sangat } \\
\text { kurang }\end{array}$ \\
\hline
\end{tabular}

Analisis data hasil tes ini merupakan data yang diperoleh dari siswa setelah diberikan soal pretest dan soal posttest tentang produk pembelajaran yang bertujuan untuk mengetahui efektivitas produk berupa tingkat penguasaan materi teks recount yang diwujudkan dalam skor tes hasil belajar setelah menggunakan produk multimedia pembelajaran yang sudah dikembangkan.

Hasil belajar siswa yang diperoleh dari pretest dan posttest kemudian dianalisis dengan membandingkan skor pretest dan skor posttest. Peningkatan hasil belajar yang terjadi sebelum dan sesudah menggunakan multimedia, diperhitungkan dengan rumus (N-gain) yang ditentukan berdasarkan rata-rata gain skor yang dinormalisasi (g) yaitu perbandingan dari skor gain. Skor gain adalah skor yang diperoleh siswa dari pretest dan posttest sedangkan skor gain maksimum yaitu skor gain tertinggi yang diperoleh siswa. Rata-rata gain yang dinormalisasi (N-gain) (Hake, 1998, p. 2) dinyatakan oleh persamaan sebagai berikut:

Keterangan :

$$
g=\frac{S \text { post }- \text { S pre }}{\text { S maks }- \text { S pre }}
$$

G : : Rata-rata gain skor yang dinormalisasi

S post : Rata-rata Skor Postes

$S$ pre : Rata-rata Skor Pretes

$S$ maks : Skor Maksimal

Nilai yang sudah diperoleh selanjutnya diinterpretasikan ke dalam tabel klasifikasi nilai Gain (Hake, 1998, p. 3) dengan kriteria yaitu sebagai berikut:

Tabel 2. Klasifikasi Nilai Gain.

\begin{tabular}{ll}
\hline Nilai & Klasifikasi \\
\hline$(\mathrm{N}$-gain $) \geq 0,7$ & Tinggi \\
$0,7>(\mathrm{N}-$ gain $) \leq 0,3$ & Sedang \\
$(\mathrm{N}$-gain $) \leq 0,3$ & Rendah \\
\hline
\end{tabular}

\section{Hasil Penelitian dan Pembahasan}

\section{Hasil Pengembangan}

Tahap perencanaan dimulai dengan mengidentifikasi bidang atau ruang lingkup materi teks recount. Tahapan ini dilaksanakan dengan mengidentifikasi Standar Kompetensi dan Kompetensi Dasar pada silabus mata pelajaran bahasa Inggris materi teks recount kelas VIII Madrasah Tsanawiyah. Silabus digunakan sebagai acuan dalam proses pembelajaran yang dituangkan ke dalam produk multimedia pembelajaran.

Identifikasi karakteristik siswa MTs kelas VIII dilaksanakan dengan mengadakan wawancara dengan 1 guru bidang 
studi bahasa Inggris dan prasurvei pada siswa kelas VIII G di MTsN II Yogyakarta dengan menggunakan angket dan observasi. Wawancara dengan 1 guru bidang studi bahasa Inggris dilakukan pada tanggal 9 November 2013, sedangkan pemberian lembar angket dan observasi pada 23 siswa kelas VIII G MTsN II Yogyakarta dilaksanakan pada tanggal 29 Maret 2014. Wawancara dan prasurvei bertujuan untuk mengetahui permasalahan yang dialami oleh siswa dalam memahami bahasa Inggris materi teks recount. Hasil prasurvei menunjukkan bahwa pembelajaran bahasa Inggris materi teks recount dengan menggunakan multimedia komputer diinginkan oleh siswa. Siswa menginginkan penggunaan video, audio, musik latar (backsound), gambar-gambar yang mendukung materi, serta warna dalam mempelajari bahasa Inggris materi teks recount. Pembelajaran bahasa Inggris di kelas telah menggunakan media video dan gambar tetapi penggunaan media-media tersebut belum terpadu. Hasil prasurvei menunjukkan bahwa siswa menyukai warna biru, merah, merah jambu (pink), hitam, putih, hijau, coklat, perak (silver), ungu. Rangkuman jumlah siswa dan jenis warna yang disukai siswa dapat dilihat pada Tabel 3 sebagai berikut.

Tabel 3. Rangkuman Jenis Warna yang Disukai Siswa dan Jumlah Siswa

\begin{tabular}{llc}
\hline No & $\begin{array}{c}\text { Jenis Warna Yang } \\
\text { Disukai Siswa }\end{array}$ & $\begin{array}{c}\text { Jumlah } \\
\text { Siswa }\end{array}$ \\
\hline 1. & Biru & 13 \\
2. & Merah & 4 \\
3. & Merah jambu (pink) & 2 \\
4. & Hitam & 7 \\
5. & Putih & 2 \\
6. & Hijau & 3 \\
7. & Coklat & 1 \\
8. & Perak (silver) & 1 \\
9. & Ungu & 1 \\
\hline
\end{tabular}

Pada pembuatan multimedia pembelajaran yang dikembangkan tidak semua warna yang disukai siswa dimasukkan. Warna yang disukai siswa dipilih dan dipilah, kemudian ditambah dengan warna kuning agar sesuai dengan teori warna pada bab dua.

Identifikasi kebutuhan teknis meliputi penggunaan perangkat keras dan lunak. Perangkat-perangkat tersebut digunakan untuk mengolah gambar tiga dimensi dan dua dimensi ( $3 D$ dan $2 D$ ), suara, dan video dalam proses pembuatan multimedia pembelajaran yang dikembangkan. Perangkat keras yang digunakan meliputi Intel @ Pentium ${ }^{\circledR}$ Dual CPU E2140@1.60 $\mathrm{GHz}$, Memory 4GB, Resolusi layar 1024×768 pixels, Sound card, VGA Radeon HD 7730. Perangkat lunak yang digunakan meliputi Microsoft Windows 7 Ultimate, Adobe Flash CS5, Makehuman 1.0.0, 3ds Max 2008, Blender 2.67, Camtasia Studio 8, Adobe Audition CS5.5, Adobe Illustrator CS3, Adobe Photoshop CS4.

Studi pustaka diperlukan untuk mengumpulkan dan menentukan sumbersumber. Studi pustaka dilakukan untuk mengumpulkan informasi, dengan mempelajari silabus mata pelajaran bahasa Inggris kelas VIII semester 1 MTs berkaitan dengan karakteristik mata pelajaran, alokasi waktu yang tersedia, kemudian membaca buku-buku mata pelajaran bahasa Inggris, dan soal-soal yang terkait yang didapatkan melalui Internet. Buku-buku yang digunakan adalah buku berjudul English in Focus for Grade VIII Junior High School (SMP/MTs) dan buku berjudul Super Cerdas Materi dan Ulangan Harian SMP/MTs Kelas 8. Soal-soal yang menjadi acuan materi adalah soal-soal Ujian Nasional Tahun Ajar 2012/2013

Diskusi ide awal dilakukan dengan satu guru pengampu mata pelajaran bahasa Inggris kelas VIII di MTsN II Yogyakarta kemudian hasil diskusi ditelaah sebelum memulai pembuatan multimedia pembelajaran. Diskusi dengan guru pengampu mata pelajaran bahasa Inggris dilakukan pada saat wawancara berlangsung, yaitu pada tanggal 9 November 2013.

Setelah tahap perencanaan telah dilaksanakan, selanjutnya tahap desain dilakukan dengan tujuan agar memper-mu- 
dah pembuatan program multimedia pembelajaran yang dikembangkan. Pada tahap ini terdapat langkah-langkah kegiatan yaitu pembuatan flowchart, pembuatan storyboard, persiapan skrip untuk narasi video penjelasan.

Produk multimedia pembelajaran yang dikembangkan menggunakan Adobe Flash CS5 dengan target pengguna siswa Madrasah Tsanawiyah (MTs) kelas VIII. Proses produksi multimedia yang dikembangkan diolah menggunakan program Adobe Flash CS 5 didukung dengan program lainnya seperti Makehuman 1.0.0, 3ds Max 2008, Blender 2.67, Camtasia Studio 8, Adobe Audition CS5.5, Adobe Illustrator CS3, dan Adobe Photoshop CS4. Ongoing evaluation dilakukan untuk mengevaluasi apakah produk multimedia pembelajaran yang dikembangkan berjalan dengan semestinya atau tidak. Kegiatan yang dilaksanakan pada tahap pengembangan adalah menyiapkan teks, warna, gambar, audio dan video, menggabungkan semua bagianbagian atau bahan-bahan yang telah disiapkan ke dalam Adobe Flash CS5 dengan menyesuaikan flowchart dan storyboard,

Setelah multimedia pembelajaran yang dikembangkan telah selesai dinilai oleh dua orang ahli materi, dua orang ahli media, dan siswa maka produk akhir telah siap untuk dapat digunakan oleh siswa. Tampilan slide-slide utama yang terdapat pada produk yang dikembangkan diantaranya adalah gambar 1 . Tampilan layar pada title page, dan gambar 2. Tampilan layar pada menu utama.

Tampilan title page berisi indetitas pengembang, judul produk, dan gambar yang relevan dengan topik dapat dilihat pada Gambar 1.

Tampilan layar menu utama berisi petunjuk, SK dan KD, uraian materi, rangkuman, kuis, evaluasi, profil pengembang, dan daftar pustaka. Petunjuk alur program ditampilkan sehingga siswa dapat menggunakan program multimedia pembelajaran setahap demi setahap. Tombol-tombol di menu utama belum bisa ditekan apabila materi pada halaman sebelumnya belum dipelajari. Tampilan menu utama dapat dilihat pada Gambar 2.

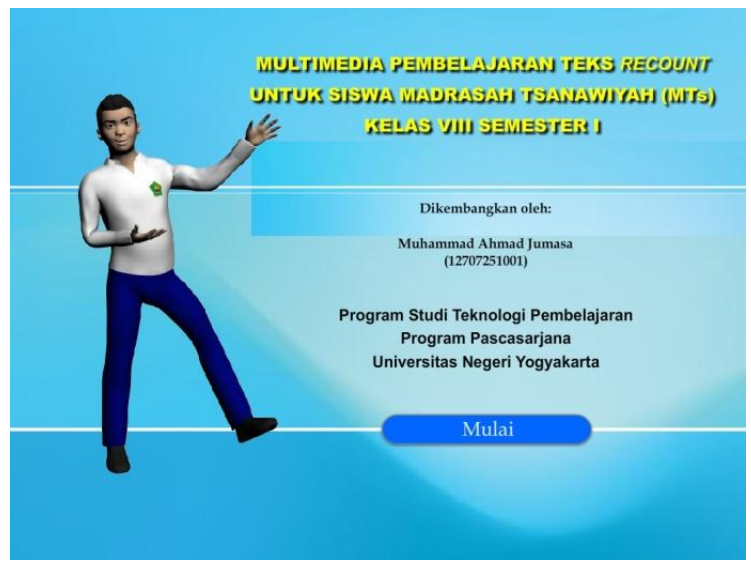

Gambar 1. Tampilan Layar pada Title Page

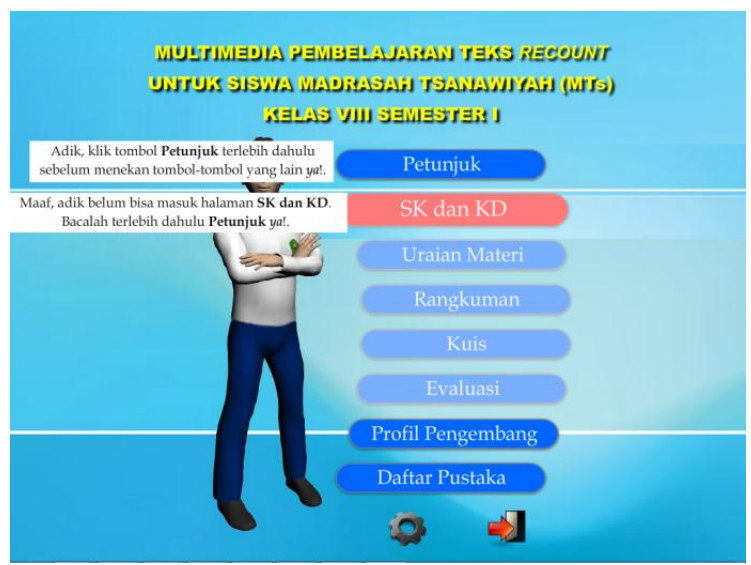

Gambar 2. Tampilan Layar pada Menu Utama

\section{Hasil Uji Alpha (Alpha Testing)}

Dalam analisis data hasil evaluasi produk ahli materi I terdapat dua aspek yang menjadi penilaian ahli materi I yaitu aspek pembelajaran dan aspek isi. Analisis data hasil penilaian produk ahli materi I didasarkan pada penilaian ahli materi I tahap II. Pada aspek pembelajaran terdapat 16 indikator penilaian, 10 indikator mendapatkan skor 5 (Sangat Baik), 6 indikator mendapatkan 4 (Baik). Hasil perhitungan rerata skor pada aspek pembelajaran adalah 4.62 dengan kategori Sangat Baik. Pada aspek isi terdapat 11 indikator penilaian, dengan rincian 8 indikator mendapatkan skor 5 (Sangat Baik) dan 3 indikator mendapatkan skor 4 (Baik). Rerata dari aspek isi ini adalah 4.72 dengan kategori Sangat Baik. 
Total keseluruhan dari aspek yang dinilai memperoleh kategori Sangat Baik dengan jumlah 126 dan rerata 4.67. Hasil penilaian oleh ahli materi I dapat dilihat pada rangkuman hasil penilaian ahli materi I Tabel 4.

Tabel 4. Rekap Hasil Penilaian Ahli Materi I

\begin{tabular}{cccc}
\hline No & $\begin{array}{c}\text { Aspek } \\
\text { Penilaian }\end{array}$ & $\begin{array}{c}\text { Rata- } \\
\text { rata }\end{array}$ & Kategori \\
\hline 1 & Pembelajaran & 4,62 & Sangat Baik \\
2 & Isi & 4,72 & Sangat Baik \\
\multicolumn{2}{l}{ Total keseluruhan } & 4,67 & Sangat Baik \\
\hline
\end{tabular}

Rentang skor: 1-5

Aspek yang menjadi penilaian ahli materi II dalam analisis hasil evaluasi produk ahli materi II yaitu aspek pembelajaran dan aspek isi. Pada aspek pembelajaran terdapat 16 indikator penilaian. 3 indikator mendapatkan skor 5 (Sangat Baik) dan 13 indikator penilaian memperoleh skor 4 (Baik). Rerata dari aspek pembelajaran ini adalah 4.18 dengan kategori Sangat Baik. Pada aspek isi terdapat 11 indikator penilaian, dengan rincian 6 indikator mendapatkan skor 5 (Sangat Baik) dan 5 indikator mendapatkan skor 4 (Baik). Rerata dari aspek isi ini adalah 4.54 dengan kategori Sangat Baik. Total keseluruhan dari dua aspek yang dinilai mendapatkan kategori Sangat Baik dengan jumlah 117 dan rerata 4.36. Hasil penilaian ahli materi II dapat dilihat pada rangkuman hasil penilaian ahli materi II Tabel 5.

Tabel 5. Rekap Hasil Penilaian Ahli Materi II

\begin{tabular}{cccc}
\hline No & $\begin{array}{c}\text { Aspek } \\
\text { Penilaian }\end{array}$ & $\begin{array}{c}\text { Rata- } \\
\text { rata }\end{array}$ & Kategori \\
\hline 1 & Pembelajaran & 4,18 & Sangat Baik \\
2 & Isi & 4,54 & Sangat Baik \\
\multicolumn{2}{l}{ Total keseluruhan } & 4,36 & Sangat Baik \\
\hline
\end{tabular}

Rentang skor: 1-5

Dalam analisis hasil evaluasi produk ahli media I terdapat dua aspek yang menjadi penilaian ahli media I yaitu aspek tampilan media dan aspek pemrograman. Pada aspek tampilan media terdapat 14 indikator penilaian. 2 indikator penilaian memperoleh skor 5 (Sangat Baik), 11 indikator penilaian memperoleh skor 4 (Baik) dan 1 indikator penilaian memperoleh skor 3 (Cukup) dengan rerata skor pada aspek tersebut adalah 4.07 dengan kategori Baik. Pada aspek pemrograman terdapat 10 indikator penilaian dengan rincian 6 indikator penilaian memperoleh skor 5 (Sangat Baik), 3 indikator penilaian memperoleh skor 4 (Baik) dan 1 indikator penilaian memperoleh skor 3 (Cukup) dengan rerata skor pada aspek tersebut adalah 4.50 dengan kategori Sangat Baik. Total keseluruhan dari dua aspek yang dinilai mendapatkan jumlah 102 dan rerata 4.28 dengan kategori Sangat Baik. Hasil penilaian ahli media I dapat dilihat pada rangkuman hasil penilaian ahli media I Tabel 6.

Tabel 6. Rekap Hasil Penilaian Ahli Media I

\begin{tabular}{cccc}
\hline No & Aspek Penilaian & $\begin{array}{c}\text { Rata- } \\
\text { rata }\end{array}$ & Kategori \\
\hline 1 & Tampilan media & 4,07 & Baik \\
2 & Pemrograman & 4,50 & Sangat Baik \\
Total keseluruhan & 4,28 & Sangat Baik \\
\hline
\end{tabular}

Rentang skor: 1-5

Penilaian ahli media II meliputi kualitas produk yang dikembangkan ditinjau dari dua aspek, yaitu aspek tampilan media dan aspek pemrograman. Aspek tampilan media terdapat 14 indikator penilaian. Semua indikator tersebut mendapatkan skor 4 (Baik) dengan rerata skor pada aspek tersebut adalah 4.00 dengan kategori Baik. Pada aspek pemrograman terdapat 10 indikator penilaian dengan rincian 6 butir mendapatkan skor 5 (Sangat Baik) dan 4 butir mendapatkan skor 4 (Baik). Hasil perhitungan rerata skor pada aspek pemrograman adalah 4.60 dengan kategori Sangat Baik. Total keseluruhan dari aspek yang dinilai memperoleh kategori Sangat Baik dengan jumlah 102 dan rerata 4.30. Hasil penilaian oleh ahli media II dapat dilihat pada rangkuman hasil penilaian ahli media II Tabel 7. 
Tabel 7. Rekap Hasil Penilaian Ahli Media II

\begin{tabular}{cccc}
\hline No & Aspek Penilaian & $\begin{array}{c}\text { Rata- } \\
\text { rata }\end{array}$ & Kategori \\
\hline 1 & Tampilan media & 4,00 & Baik \\
2 & Pemrograman & 4,60 & Sangat Baik \\
Total keseluruhan & 4,30 & Sangat Baik \\
\hline
\end{tabular}

Rentang skor: 1-5

Hasil Uji Beta (Beta Testing)

Aspek yang menjadi penilaian siswa dalam uji beta (beta testing) yaitu aspek pembelajaran, aspek materi, dan aspek tampilan. Hasil penilaian siswa pada uji ini menunjukkan bahwa dari 12 indikator yang dinilai oleh 30 siswa kelas VIII C MTsN II Yogyakarta memperoleh kategori Sangat Baik untuk aspek pembelajaran dengan rerata 4.20, kategori Sangat Baik untuk aspek materi dengan rerata 4.28 , dan kategori Sangat Baik untuk aspek tampilan dengan rerata 4.10. Hasil rangkuman penilaian oleh siswa pada uji beta (beta testing) dapat dilihat pada Tabel 8 .

Tabel 8. Rekap Hasil Uji Beta (Beta Testing).

\begin{tabular}{clrl}
\hline No & Aspek Penilaian & $\begin{array}{c}\text { Rata- } \\
\text { rata }\end{array}$ & Kategori \\
\hline 1 & Pembelajaran & 4.20 & Sangat Baik \\
2 & Materi & 4.28 & Sangat Baik \\
3 & Tampilan & 4.10 & Sangat Baik \\
Total keseluruhan & 4.19 & Sangat Baik
\end{tabular}
Rentang skor: 1-5

Penilaian siswa terhadap produk multimedia pembelajaran yang dikembangkan memperoleh jumlah nilai rerata skor yaitu 4.19. Dengan demikian produk multimedia pembelajaran yang dikembangkan dapat dinyatakan sangat baik dan layak untuk digunakan dalam pembelajaran bahasa Inggris untuk pembelajaran materi teks recount di MTsN II Yogyakarta.

\section{Hasil Validasi Program}

\section{Hasil Uji Coba Produk}

Uji coba produk dilaksanakan dengan subjek uji coba berjumlah 34 orang siswa dari kelas VIII G di laboratorium komputer MTsN II Yogyakarta. Lembar angket diberikan setelah siswa menggunakan produk multimedia pembelajaran yang dikembangkan. Ujicoba produk dilakukan 4 jam pelajaran atau 4 kali 40 menit. Jam pelajaran pertama dan kedua dilaksanakan pada hari selasa tanggal 6 Januari 2015 di jam ke 7 atau jam 11.35 sebelum istirahat dan ke 9 atau jam 12.55 setelah istirahat. Jam pelajaran ketiga dan keempat dilaksanakan pada hari selasa tanggal 20 Januari 2015 di jam ke 5 atau jam 10.15 dan di jam ke 6 atau jam 10.55. Hasil rangkuman penilaian siswa pada lembar angket dapat dilihat pada Tabel 9.

Tabel 9. Rekap Hasil Penilaian Siswa pada Uji Coba Produk.

\begin{tabular}{clcc}
\hline No & Aspek Penilaian & Rata-rata & Kategori \\
\hline 1 & Pembelajaran & 3,92 & Baik \\
2 & Materi & 4,05 & Baik \\
3 & Tampilan & 3,80 & Baik \\
Total keseluruhan & 3,92 & Baik \\
\hline Rentang skor: $1-5$
\end{tabular}

Ada 3 aspek yang menjadi penilaian dari produk multimedia pembelajaran yang dikembangkan yaitu aspek pembelajaran berjumlah 3 indikator, aspek materi berjumlah 4 indikator, dan aspek tampilan berjumlah 5 indikator. Tabel diatas menunjukkan bahwa siswa memberikan nilai positif atau kategori baik terhadap pernyataan-pernyataan yang diberikan dengan memperoleh rata-rata 3.92 dari 3 aspek yang dinilai. Pada aspek pembelajaran total nilai yang diperoleh yaitu 389 dengan ratarata 3.92 dengan kategori Baik. Pada aspek materi dengan 4 indikator yang diberikan total skor yang diperoleh yaitu 536 dengan rata-rata 4.05 dan memiliki kriteria Baik. Pada aspek tampilan, penilaian siswa berdasarkan Tabel 9 memperoleh jumlah skor 628 dengan rata-rata 3.80 .

Hasil Belajar (Pretest dan Postest)

Pretest dan postest dilaksanakan untuk mengetahui keefektifan produk multimedia pembelajaran yang dikembangkan 
dalam meningkatkan hasil belajar siswa untuk materi teks recount. Perubahan skor hasil belajar dihitung dengan teknik standar gain, yaitu kenaikan skor diperoleh dari skor akhir (posttest) dikurangi skor awal (pretest) kemudian dibagi dengan hasil pengurangan antara skor maksimum dengan skor awal (pretest). Kriteria efektifitas produk ditentukan berdasarkan hasil pretest dan posttest siswa ditinjau dari jumlah ratarata indeks gain score seluruh siswa kelas VIII G yang mengikuti tes pretest dan tes posttest.

Sebanyak 28 siswa (88\%) termasuk dalam kategori tinggi sedangkan 3 siswa (9\%) termasuk kategori sedang, dan 1 siswa $(3 \%)$ termasuk kategori rendah. Berdasarkan tabel klasifikasi nilai gain yang diperoleh, maka keefektifan dari produk yang dikembangkan termasuk dalam klasifikasi tinggi yaitu sebesar $0,90(N$-gain $\geq$ $0,7)$ yang dilihat dari jumlah rata-rata indeks gain score seluruh siswa kelas VIII G yang mengikuti tes pretest dan posttest. Diagram perolehan klasifikasi gain siswa dapat dilihat pada Gambar 3.

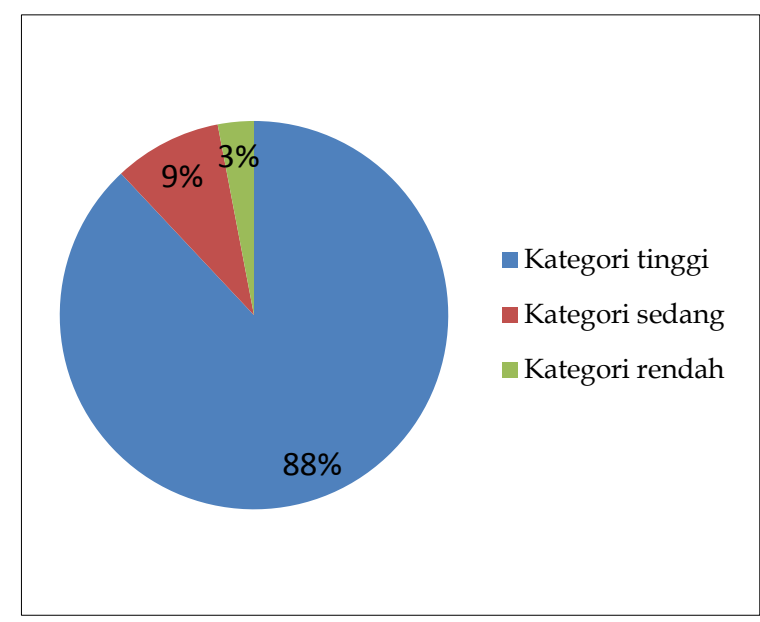

Gambar 3. Klasifikasi Perolehan Skor Gain Siswa

Pembahasan

Produk multimedia pembelajaran bahasa Inggris untuk pembelajaran teks recount yang dibuat dengan menggunakan perangkat lunak Adobe Flash CS5 dan perangkat lunak pendukung lainnya merupakan salah satu sumber belajar pelengkap yang bertujuan untuk memudahkan siswa memperkaya perbendaharaan kata bahasa inggris pada materi teks recount, mempermudah siswa untuk menyusun rangkaian peristiwa berbentuk paragraf acak dari teks recount, serta mempermudah siswa untuk memahami perubahan bentuk kata kerja masa lampau dalam teks recount. Produk multimedia pembelajaran yang dikembangkan menggunakan tujuh prinsip dari 12 prinsip Mayer (2010, pp. 267-268), yaitu prinsip koherensi, prinsip pemberian isyarat atau tanda (signaling), prinsip keterdekatan ruang, prinsip pemotongan (segmenting), prinsip pra-latihan (pre-training), prinsip multimedia, dan prinsip personalisasi (personalization). Bentuk penerapan prinsip koherensi pada multimedia yang dikembangkan yaitu penggunaan gambar-gambar yang sesuai dengan arti setiap kalimat pada setiap paragraf teks recount. Bentuk penerapan prinsip pemberian isyarat atau tanda (signaling) yaitu pemberian tanda berwarna kuning pada setiap kata yang berfungsi untuk mengetahui arti dari setiap kata tersebut dengan cara mengarahkan tanda panah tetikus (mouse) pada tanda-tanda tersebut. Bentuk penerapan prinsip keterdekatan ruang adalah pada keterdekatan antara kalimat-kalimat pada paragraf teks recount dan gambar yang terkait dengan kalimat-kalimat tersebut pada 1 layar. Bentuk penerapan prinsip pemotongan (segmenting) pada multimedia pembelajaran yang dikembangkan adalah setiap video dibagi menjadi enam tema yang berbeda-beda dan tidak menjadi satu video penuh. Prinsip ini juga diterapkan pada bentuk-bentuk teks recount yang dibagi menjadi tiga paragraf sehingga siswa mudah mengetahui arti dari setiap kalimat pada paragraf-paragraf tersebut. Bentuk penerapan prinsip pra-latihan (pre-training) pada multimedia pembelajaran yang dikembangkan yaitu penggunaan video untuk menjelaskan karakteristik dari konsepkonsep utama materi teks recount seperti pengertian teks recount, tujuan teks recount, generic structure teks recount dan karakteristik teks recount yang meliputi peng- 
gunaan subject pronoun, sequence words, dan simple past tense. Bentuk penerapan prinsip multimedia adalah pada penggunaan gambar dan kata-kata pada setiap paragraf-paragraf teks recount. Bentuk penerapan prinsip personalisasi (personalization) di dalam multimedia pembelajaran yang dikembangkan yaitu pada kalimat-kalimat perintah yang menggunakan bahasa percakapan dan bukan bahasa formal.

Multimedia yang dikembangkan dibuat berdasarkan pada beberapa teori belajar dan pembelajaran bahasa yaitu behavioristik, kognitif, konstruktivistik, dan semiotik sosial. Konsep teori behavioristik pada penelitian ini didasarkan pada pendapat Thorndike (1923, pp. 1-4) dan Thorndike (1923, p. 96). Bentuk penerapan hukum kesiapan di dalam produk multimedia bahasa Inggris tentang materi teks recount adalah pada penetapan standar kompetensi, kompetensi dasar, dan indikator yang akan dicapai. Standar kompetensi, kompetensi dasar, dan indikator disesuaikan dengan tingkat kesiapan siswa untuk menerima materi pembelajaran, yaitu siswa sudah berada di kelas VIII MTs dan siswa sudah mempelajari materi teks fungsional pendek dan teks deskriptif.

Bentuk penerapan hukum latihan pada produk multimedia dalam penelitian ini adalah pada pemberian soal-soal kuis. Soal-soal kuis berupa paragraf-paragraf acak yang harus disusun oleh siswa agar menjadi teks recount yang utuh, dan rumpang teks yang harus dilengkapi dengan kata kerja masa lampau dan kata kerja bantu masa lampau yang tepat.

Bentuk penerapan hukum pengaruh pada produk adalah pada penyajian animasi yang didapat siswa apabila siswa mendapat nilai tertentu setelah kuis selesai dikerjakan. Jika siswa mendapat nilai di bawah 70 siswa akan dimotivasi untuk mengerjakan kembali sedangkan jika siswa sudah mendapat nilai 100 siswa akan diberi pujian.

Penerapan teori kognitif pada multimedia pembelajaran yang dikembangkan berdasarkan pada tiga asumsi yang dike- mukakan oleh Mayer (2010, pp. 64-68). Tiga asumsi tersebut adalah asumsi DualChannel (saluran ganda), asumsi kapasitas terbatas, dan pemrosesan aktif. Teori kognitif pada penelitian ini diterapkan pada contoh kalimat. Penerapan asumsi kapasitas terbatas terdapat pada kalimat-kalimat bahasa Inggris yang dipotong menjadi bagian-bagian kecil kata, kemudian potongan-potongan kata tersebut dapat diakses oleh siswa sehingga memudahkan siswa untuk merangkai arti bahasa Indonesia dari kalimat bahasa Inggris tersebut secara utuh. Video-video materi berdurasi singkat memberikan pengetahuan awal pada siswa tentang aturan penyusunan paragraf, penggunaan sequence words (katakata urutan), dan penggunaan kata kerja dan kata kerja bantu masa lampau pada suatu teks recount. Pada contoh, paragraf kalimat tersusun atas tombol-tombol persegi panjang berwarna kuning agar memudahkan siswa merangkai pengetahuan baru mengenai contoh tersebut dengan pengetahuan yang telah dimiliki melalui video-video materi. Kalimat-kalimat contoh menggunakan kata-kata urutan, katakata kerja dan kata-kata kerja bantu masa lampau sehingga siswa dapat menghubungkan pengetahuan awal (pengetahuan yang didapat melalui video) dengan pengetahuan baru berupa contoh kalimat. Penggunaan kalimat dan gambar yang sesuai pada contoh tanpa suara narasi (visual pictorial) agar tidak membebani memori kerja (Working Memory).

Teori konstruktivistik pada penelitian ini diterapkan pada pemilihan potongan-potongan kata dan kalimat yang ada pada bagian contoh-contoh teks recount. Pengetahuan siswa tentang bentuk dan penggunaan kata-kata urutan, kata-kata kerja dan kata-kata kerja bantu masa lampau akan terbentuk melalui proses interaksi siswa dengan sajian gambar, kalimatkalimat contoh dan potongan-potongan kata, semakin banyak mereka berinteraksi dengan contoh tersebut, semakin rinci pula pengetahuan dan pemahaman mereka sendiri tentang materi tersebut. Penerapan 
teori konstruktivistik pada multimedia pembelajaran yang dikembangkan juga terdapat pada soal-soal kuis. Siswa berinteraksi dengan soal-soal berbentuk drag and drop (seret dan jatuhkan) tentang perangkaian kalimat-kalimat acak menjadi bentuk teks recount dengan susunan yang benar dan juga tentang perubahan kata kerja masa sekarang menjadi kata kerja masa lampau. Siswa menggunakan pengetahuan-pengetahuan yang sudah ada yang telah dijelaskan pada video penjelasan dan pengalaman-pengalaman ketika berinteraksi dengan contoh-contoh teks recount, kemudian siswa mendapatkan pengetahuan yang baru melalui interaksi dengan soal-soal kuis. Pengetahuan yang telah ada, pengalaman, dan pengetahuan yang baru dipilih dan diubah oleh siswa sehingga menjadi pengetahuan dan pemahaman pribadi yang baru.

Konsep teori semiotik sosial pada penelitian ini merujuk pada pendapat Halliday (2007, p. 274), Brown dan Yule (1986, p. 25), Eggins (2004, p. 88) dan Malinowski (Eggins, 2004, p. 88). Penerapan teori semiotik sosial pada multimedia yang dikembangkan adalah pada penggunaan teks-teks recount dan teks pada halaman awal contoh recount. Teks-teks recount pada multimedia yang dikembangkan merupakan teks yang sesuai dengan konteks situasi ketika teks-teks tersebut dibuat. Konteks budaya diterapkan pada penggunaan kalimat Assalammu'alaikum sebagai budaya menyapa dilingkungan Madrasah Tsanawiyah pada halaman awal contoh recount.

Produk multimedia yang dikembangkan menggunakan musik sebagai musik latar karena musik memiliki manfaat untuk menghibur, membawa suasana santai ketika pembelajaran berlangsung, serta mempengaruhi emosi secara positif. Hal ini seusai dengan pendapat Harmer (2007, p. 319), Hoffer (1985, p. 10), Djohan (2009, p. 109), dan Jensen (2001, p. 14).

Setelah dilakukan uji alpha (penilaian yang dilakukan oleh dua orang ahli materi dan dua orang ahli media), uji beta, dan uji coba produk pada validasi program terbukti bahwa penggunaan multimedia pembelajaran tentang materi teks recount yang dikembangkan secara efektif dapat meningkatkan hasil belajar siswa. Dari hasil pretest dan posttest yang dilakukan terjadi peningkatan nilai siswa. Peningkatan nilai tersebut merupakan efek dari treatment yang dilakukan dengan melihat selisih antara hasil pretest dengan hasil posttest. Treatment yang disajikan dalam multimedia yang dikembangkan didukung dengan adanya gambar-gambar, video, dan musik yang ditampilkan melalui komputer dengan menarik, dan soal kuis yang dapat dikerjakan secara mandiri atau kelompok.

Kualitas produk multimedia yang dikembangkan dapat digolongkan sangat bagus atau sangat baik. Hal ini dibuktikan dari komentar yang diperoleh melalui angket siswa pada uji beta dan uji coba produk. Siswa pada uji beta dan uji coba produk memberikan komentar berupa kesan bahwa produk multimedia pembelajaran yang dikembangkan menarik, menyenangkan dan memudahkan mereka untuk memahami materi teks recount.

Produk multimedia pembelajaran yang dikembangkan mempunyai beberapa keunggulan sekaligus mempunyai kekurangan serta keterbatasan yang harus diperhatikan. Keunggulan dari produk multimedia pembelajaran yang dikembangkan yaitu mampu menghemat waktu belajar, memotivasi belajar bahasa Inggris siswa tentang materi teks recount, mempermudah siswa untuk mempelajari bahasa Inggris materi teks recount.

Keunggulan pertama yaitu dapat menghemat waktu belajar. Hal ini dibuktikan dari catatan waktu yang diperoleh selama pembelajaran berlangsung dengan menggunakan program multimedia yang dikembangkan pada setiap jam pelajaran. Waktu yang ada pada silabus untuk kemampuan menulis teks recount adalah 4 jam pelajaran atau $4 \times 40$ menit. Pada jam pelajaran pertama siswa membutuhkan waktu 14 menit 59.5 detik. Pada jam pel- 
ajaran kedua siswa membutuhkan waktu 28 menit 46.1 detik. Pada jam pelajaran ketiga siswa membutuhkan waktu 9 menit 45.2 detik. Pada jam pelajaran keempat siswa membutuhkan waktu 8 menit 12.4 detik.

Keunggulan kedua yaitu dapat memotivasi belajar bahasa Inggris siswa tentang materi teks recount. Hal ini dibuktikan dari pengamatan pada saat uji coba produk dilaksanakan. Pada pengamatan di jam pelajaran kedua diketahui ada tiga siswa mencatat penjelasan dalam video tanpa diperintahkan. Pada pengamatan di jam pelajaran keempat diketahui ada dua siswa antusias untuk mengerjakan kuis yang ada pada program multimedia pembelajaran yang dikembangkan. Hasilhasil pengamatan tersebut membuktikan bahwa multimedia pembelajaran yang dikembangkan dapat memotivasi siswa untuk mempelajari materi teks recount.

Keunggulan ketiga adalah dapat mempermudah siswa untuk mempelajari bahasa Inggris materi teks recount. Hal ini dapat dilihat dari komentar dan saran revisi dari siswa pada uji beta dan uji coba produk. Siswa memberi komentar bahwa produk multimedia pembelajaran yang dikembangkan dapat membantu siswa untuk mempelajari materi teks recount dengan mudah. Dua siswa pada uji coba produk memberi komentar bahwa mereka menginginkan produk multimedia pembelajaran yang dikembangkan tidak hanya dibuat untuk materi teks recount saja tetapi juga untuk materi jenis teks lainnya. Hal ini membuktikan bahwa produk yang dikembangkan membantu mereka dalam memahami materi pelajaran bahasa Inggris sehingga mereka mengharapkan penambahan materi jenis teks lain selain teks recount pada produk multimedia pembelajaran yang dikembangkan.

Produk multimedia pembelajaran yang dikembangkan memiliki beberapa kelemahan dan keterbatasan. Kelemahan dari produk yang dibuat yaitu tidak dapat disebarkan melalui media internet karena produk ini mempunyai kapasitas file yang besar. Kelemahan lain dari produk yang dikembangkan adalah soal-soal yang ada di dalam program multimedia pembelajaran yang dikembangkan tidak dapat diperbaharui sendiri oleh guru. Produk multimedia pembelajaran yang dikembangkan tidak mempunyai soal kuis yang teracak secara otomatis. Produk yang dikembangkan hanya dirancang untuk keterampilan menulis. Dengan produk multimedia pembelajaran yang dikembangkan ini diharapkan dapat menjadi salah satu sumber belajar pelengkap yang dapat membantu memecahkan masalah belajar pada materi teks recount. Bagi guru produk multimedia pembelajaran yang dikembangkan dapat digunakan sebagai media pelengkap ajar.

\section{Simpulan dan Saran}

Hasil penelitian dan pengembangan program multimedia pembelajaran bahasa Inggris untuk pembelajaran teks recount diperoleh hasil berupa karakteristik produk yang dihasilkan mencakup petunjuk, Standar Kompetensi dan Kompetensi Dasar (SK dan KD), uraian materi, rangkuman, kuis, dan evaluasi. Petunjuk terdiri dari petunjuk belajar dan petunjuk program. Standar Kompetensi dan Kompetensi Dasar (SK dan KD) meliputi Standar Kompetensi, Kompetensi Dasar, dan Indikator. Uraian materi berisi video penjelasan, dan bentuk-bentuk teks recount. Rangkuman merupakan sekilas materi yang penting untuk dipahami siswa. Kuis berbentuk drag and drop items dan multiplechoice items. Evaluasi yang disajikan berbentuk multiple-choice items.

Produk yang dikembangkan layak digunakan sebagai salah satu sumber belajar pelengkap ditinjau dari penilaian ahli materi I pada aspek pembelajaran yang memperoleh nilai rata-rata 4,62 dengan kategori Sangat Baik dan aspek isi yang memperoleh nilai rata-rata 4,72 dengan kategori Sangat Baik. Penilaian ahli materi II pada aspek pembelajaran mendapatkan nilai rata-rata 4,18 dengan kategori Sangat Baik dan aspek isi memperoleh nilai rata- 
rata 4,54 dengan kategori Sangat Baik. Penilaian ahli media I pada aspek tampilan media memperoleh nilai rata-rata 4,07 dengan kategori Baik dan aspek pemrograman memperoleh nilai rata-rata 4,50 dengan kategori Sangat Baik. Penilaian ahli media II pada aspek tampilan media mendapatkan nilai rata-rata 4,00 dengan kategori Baik dan aspek pemrograman memperoleh nilai rata-rata 4,60 dengan kategori Sangat Baik.Hasil uji beta (beta testing) memperoleh nilai rata-rata 4,19 dengan kategori Sangat Baik. Hasil uji coba produk memperoleh nilai rata-rata 3,92 dengan kategori Baik. Peningkatan skor gain (gain score) rata-rata seluruh siswa dari hasil pretest dan posttest sebesar 0,90 ( $N$-gain $\geq 0,7)$. Hal ini berarti keefektifan produk yang dikembangkan termasuk kategori tinggi.

Pemanfaatan program multimedia pembelajaran bahasa Inggris untuk pembelajaran teks recount efektif hasilnya apabila guru menggunakannya dengan cara yang tepat. Saran pemanfaatan dalam menggunakan program multimedia pembelajaran yaitu guru menjelaskan terlebih dahulu kepada siswa tentang program dan penggunaannya dengan tujuan agar siswa lebih mudah memahami materi yang disajikan. Guru dapat memanfaatkan produk multimedia pembelajaran ini setelah guru menerangkan materi teks recount di kelas. Produk ini hanya berfungsi sebagai sumber belajar pelengkap dan bukan sebagai pengganti peran guru.

Bagi siswa, agar pemanfaatan program multimedia pembelajaran berguna dan bermanfaat hendaknya mengikuti saransaran yaitu siswa membaca dan mempelajari keseluruhan materi secara berurutan dimulai dari petunjuk, Standar Kompetensi dan Kompetensi Dasar (SK dan KD), materi, rangkuman, kuis, dan evaluasi. Diskusikan dengan guru atau teman sebaya jika terdapat kesulitan dalam menjalankan program atau materi yang tidak dipahami. Siswa hendaknya memperhatikan petunjuk-petunjuk pada program sehingga siswa dapat mengoperasionalkan program dengan mudah.
Produk multimedia ini dapat dipakai sebagai salah satu sumber belajar pelengkap bagi siswa Madrasah Tsanawiyah (MTs) dan disebarluaskan di sekolahsekolah MTs secara langsung yang dapat diduplikasi atau dikemas menggunakan CD atau DVD. Produk ini tidak dapat disebarkan melalui media internet karena produk ini mempunyai kapasitas file yang besar. Penelitian dan pengembangan lebih lanjut hendaknya dapat memperhatikan kebutuhan siswa sehingga dapat membantu dan memberikan kontribusi besar dalam meningkatkan pemahaman konsep. Penelitian dan pengembangan lebih lanjut dapat menambahkan kelengkapan komponen yang belum tersedia seperti cakupan materi yang lebih luas, penambahan audio narasi untuk membimbing siswa pada setiap halaman program, penambahan jumlah soal kuis dan evaluasi, pembuatan soal kuis dan evaluasi yang dapat diacak, penambahan tampilan animasi yang lebih banyak lagi sehingga tampilan program akan semakin menarik minat siswa untuk menjalankan program, dan pembuatan soal-soal di dalam multimedia pembelajaran yang dapat diperbaharui sendiri oleh guru dengan menggunakan XML (Extensible Markup Language). Kemampuan berbicara bahasa Inggris hendaknya dapat diterapkan pada pengembangan program lebih lanjut.

\section{Daftar Pustaka}

Alessi, S. M., \& Trollip, S. R. (2001). Multimedia for learning: Methods and development. Boston: Pearson Education Company.

Brown, G., \& Yule, G. (1986). Discourse analysis. New York: Cambridge University Press.

Djohan. (2009). Psikologi musik. Yogyakarta: Best Publisher.

Eggins, S. (2004). An introduction to systemic functional linguistics (2nd ed.). New York: Continuum International Publishing Group. 
Hake, R. R. (1998). Interactive engagement versus traditional methods: a sixthousand-student survey of mechanics test data for introductory physics course [Versi elektronik]. American Journal of Physics: Volume 66, Issue 1, Pages 64-74

Halliday, M. A. K. (2007). The notion of "context" in language education. Dalam J. J. Webster (Eds.), Language and Education (pp. 269-290). New York: Continuum.

Harmer, J. (2007). The practice of english language teaching ( $4^{\text {th }}$ ed.). Harlow: Pearson Education Limited.

Heinick, R., et.al, (1996). Instructional media and technologies for learning (5 $5^{\text {th }} \mathrm{ed}$.). New Jersey: Prentice Hall.

Hoffer, C. R. (1985). The understanding of music (5 ed.). California: Wadsworth Publishing Company.

Jensen, E. (2001). Arts with the brain in mind. Alexandria: Association for Supervision and Curriculum Development.
Kemdikbud. (2013). Peraturan Pemerintah RI Nomor 32, Tahun 2013, tentang Standar Nasional Pendidikan.

Mayer, R. E. (2010). Multimedia learning (2nd ed.). Cambridge: Cambridge University Press.

Parel, M.F., \& Jain, P. M. (2008). English language teaching:Methods, tools, $\mathcal{E}$ techniques. Valshali Nagar: Sunrise Publishers \& Distributors.

Sukardjo \& Sari, L. P. (2008). Penilaian hasil belajar Kimia. Yogyakarta: Universitas NegeriYogyakarta.

Thorndike, E. L. (1923). The Psychology of learning (Vols. 2). New York: Columbia University.

Thorndike, E. L. (1923). Education (Vols. 1). New York: The Macmillan Company.

Vaughan, T. (2011). Multimedia: Making it work (8th ed.). London: The McGrawHill, Inc. 